\title{
Research on cross culture teaching in College English teaching based on the concept of "Internet +"
}

\author{
Sha Zhang \\ Nanyang institute of technology, Henan, China, 473000
}

Keywords: Internet; College English; Cross-cultural training; Teaching

Abstract: With the rapid development of Internet, it is imperative to build a new teaching mode from "Internet +". Therefore, cross-cultural English teaching is not only an innovative way of English teaching, but also an important breakthrough in the reform of College English teaching. In order to effectively avoid the phenomenon of Chinned, teachers need to actively and correctly guide students to truly master the language of English and to use it correctly. Therefore, it is necessary to actively promote and use cross-cultural English teaching model in the process of College English teaching. This paper makes an in-depth study on the intercultural teaching mode of College English, and analyses the existing problems, and puts forward relevant improvement strategies.

With the development of society, the development of all walks of life is supported by the Internet. To varying degrees, it is also affected by the Internet, which is also true in College English teaching. The appearance of "Internet +" has broken the monopoly of traditional educational resources in the region, and the dissemination of knowledge and information has broken through the restrictions of region and school. Students can get the resources they want no matter where they are, which opens up a new way to transfer knowledge. Under the influence of "Internet +", many teaching practice innovations have sprung up. With the rapid development of science and technology, the "Internet +" mode will become an important direction of future teaching development.

\section{New requirements for college English teaching in the era of "Internet +"}

Table 1. New requirements for College English Teaching in the era of "Internet +"

\begin{tabular}{|ll|}
\hline New requirements for College English Teaching in the era of "Internet +" \\
\hline$\bullet$ & Challenges to Learning Ideas and Ways \\
\hline$\bullet$ & Challenges to Teaching Methods and Means \\
\hline$\bullet$ & Challenges to Reteaching Skills \\
\hline
\end{tabular}

The combination of modern information technology and college English teaching not only brings new challenges to traditional teaching modes, but also puts forward new requirements for reteaching methods and concepts. At the same time, it also presents a new challenge to students' autonomous learning ability. As shown in Table 1. 


\subsection{Challenges to learning ideas and ways}

In the new era, the main body of College English teaching has changed fundamentally. The main body of teaching activities has gradually changed from teachers to students, and students have changed from passive receivers to active learners. Through the Internet, students can actively receive information and knowledge from various platforms. Teachers have changed from traditional knowledge inculcate to supervisors and guides of denuclearizing, supervising the learning situation, and playing the role of answer in the process of students' learning. The enhancement of interactivity is a striking feature of College English Teaching in the era of Internet plus.

\subsection{Challenges to Teaching Methods and Means}

In the new era, the traditional blackboard plus chalk teaching mode gradually disappeared, and changed to rely on multimedia teaching mode. In contrast, although this method has made some progress and made the classroom more lively and interesting, the interaction is still insufficient. Under the background of global openness, the global knowledge base has gradually formed and expanded rapidly. High-quality educational resources are being greatly enriched and enriched. These resources are connected through the Internet, so students can get the learning resources they need anytime and anywhere.

Moreover, the emergence of various kinds of learning APP makes teachers no longer the only way for students to acquire knowledge, and the change of reteaching methods and concepts is inevitable. Because of the uneven quality of network knowledge, teachers play a more important role in checking self-fulfilment materials in teaching. Teachers need to screen the network resources that students acquire in the process of learning, or make knowledge resources suitable for students in our school, upload them to the network for students to learn.

\subsection{Challenges to Reteaching skills}

In the traditional teaching mode, what teachers should do is to write chalk well and master relevant professional knowledge and skills. However, in the era of "Internet +", teachers' teaching requirements are higher. Besides the need to master modern information technology, they must integrate with teaching. Using the Internet, making teaching videos becomes a necessary skill. Under the new situation, schoolteacher control ability is particularly important, and the ability to summarize and extract knowledge is even more indispensable. At the same time, it puts forward higher requirements for the corresponding classroom organizational ability, such as group cooperative learning for the whole class, teaching students in accordance with their aptitude, and so on. In addition, we need good information technology application capabilities, such as mainstream social and learning software use.

\section{Necessity of College English Teaching Reform in the Cross-cultural Field}

Language and culture are closely related. It is impossible to create an independent language if we want to transcend culture. In College English education and teaching, the main purpose of English learning is to cultivate demonstrability to use English and social skills. Firstly, college students should have a certain understanding and mastery of the cultural background of English when they are learning English. Effective use of cross-cultural English teaching mode can help college students understand the cultural background of English effectively, and also understand the cultural differences among different nationalities, so as to promote college students to further study English.

Secondly, cross-cultural English teaching has transformed the traditional form of College 
English teaching to a certain extent, and at the same time, it has effectively improved college studentship cultural literacy. Thirdly, College English teaching and learning need a process. Therefore, in the process of teaching and learning, it is necessary for college students to have a thorough understanding of the content of knowledge and to understand the effective use of English communication. All these contents need to be carried out in the mode of cross-cultural English teaching.

\section{Strategies to Strengthen College English Teaching in Cross-cultural Education Model}

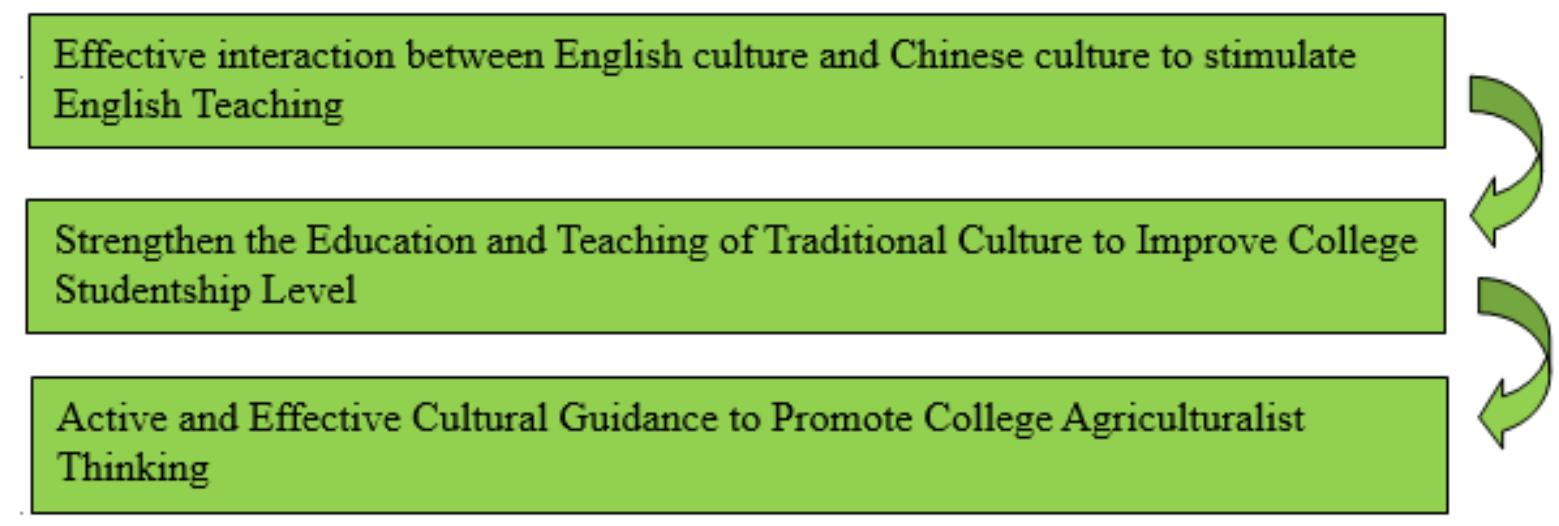

Figure 1. Strategies to Strengthen College English Teaching in Cross-cultural Education Model

As shown in Figure1, a detailed analysis is presented below.

\subsection{Effective interaction between English culture and Chinese culture to stimulate English teaching}

At present, the English teaching mode in China is relatively mature, but this mature teaching is the hard teaching of English language skills and the content teaching of knowledge. Although College English teaching in China is aware of this, the cultural teaching model in College English teaching is still relatively lacking, and the practical research is not thorough enough. China is a big country with a long cultural history. The position of Chinese culture in English education and teaching should be affirmed to a certain extent. But nowadays, many teachers and relevant people do not integrate the two in education and teaching. The lack of interaction between Chinese culture and English culture weakens the nature of the combination between English culture and Chinese. Secondly, the cultural values of college students are formed and created by Chinese culture. If the cultural content of their mother tongue is neglected in English teaching, two situations will arise: one is the sense of distance in English learning, which will always exist; the other is the dependence on foreign culture. Both of them are incorrect ideas, which will eventually lead to the failure of teaching in intercultural communication.

\subsection{Strengthen the education and teaching of traditional culture to improve college studentship level}

In English teaching in many colleges and universities, teachers will be very important for students to teach foreign cultural knowledge, so it will greatly strengthen the education and teaching of foreign national culture. However, it is necessary to strengthen the teaching of Chinese traditional culture in English teaching. First, in the process of College English education and 
teaching, English teachers should make language comparison between Chinese and English, so as to effectively let college students understand the content of Chinese cultural knowledge while learning English, which can strengthen misunderstanding and understanding of language differences. Secondly, cultural comparison between Chinese and English should be added in English teaching. Because there are great differences between Chinese and Western cultures, especially when explaining foreign festivals, history, culture and beliefs in College English teaching, using the mode of contrasting Chinese and Western cultures to teach can effectively strengthen college misunderstanding of traditional culture. Furthermore, it promotes the nonadministrative in learning. Third, as the saying goes, interest is the best teacher. Mechanical English teaching mode will make students lose enthusiasm and interest in English learning, which is not conducive to the construction of English teaching. Therefore, it is necessary for college English teachers to take cultural teaching as a supplement in their teaching and learning so as to help college students build up confidence and interest in English learning, so as to enhance the positive effectiveness of college studentship learning.

\subsection{Active and effective cultural guidance to promote college agriculturalist thinking}

If knowledge in College English teaching depends on classroom teaching, it is very difficult to support the actual needs of English teaching. In the process, college students need to make full use of classroom learning, but also need to make full use of extra-curricular learning time to enhance their understanding of the remaining learning and cultural knowledge. So in the process of cultural education and teaching, teachers should actively guide and help students, so that students can change their attitudes in English learning, and more actively enter the mode of English learning.

Therefore, English teachers can carry out English teaching from the following aspects: the first is to actively guide and organize college students to collect information about foreign cultures, such as teachers can create Christmas or Halloween themes for students to collect materials, and college students can use the collected data to study and understand them, so as to strengthen the collection. Misunderstanding of English culture can stimulate students' interest in English learning. In addition, screenwriting and exploring spirit can be cultivated in the process to further strengthen students' cross-cultural awareness. Secondly, on the basis of the original classroom content, a special course of appreciation of English and American literature is created. This teaching mode can help college students understand more intuitively the customs, customs, literature and art of foreign countries, thus strengthening their understanding of English culture.

The third is to let foreign teachers of English make relevant reports to explain the content of cultural etiquette to college students. Fourthly, it is necessary to effectively carry out the constitutional teaching of English thematic activities so that college students can understand the cultural content of English abroad in constitutional activities, and to compare and compare with Chinese culture so as to understand the cultural connotation and content of English. In these teaching processes, agriculturalist vision can be entrusted, and their cultural accomplishment can be strengthened. At the same time, students' intercultural communicative competence can be effectively improved.

\section{Conclusion}

Combining with the full text, English is a very important subject in our country's teaching at present, and the extensive application of English is also becoming increasingly apparent. English is not only a tool for communication and interaction, but also a necessary weapon in international competition. Therefore, it is necessary to change the traditional English teaching mode and viewpoint, and effectively change the skeleton-only English teaching mode in the past. Emphasis 
should be placed on the cross-cultural English teaching model so as to continuously develop the scope of cross-cultural knowledge. Gradually enhance the dual teaching consciousness of English teaching. Only by using this teaching mode, can the overall level of studentship be effectively improved, and it is also the necessary standard for training comprehensive talents.

\section{References}

[1] Mia Juan. Analysis of problems and Countermeasures in cross-cultural teaching of College English [J]. Electronic Journal in the New Educational Era (Teacher Edition), 2015 (14).

[2] Fang Lina. Problems and Countermeasures in intercultural English teaching in Colleges and universities [J]. Modern Communication (Academic Edition), 2016 (17): 174-174.

[3] Li Ling. Model Construction of Cross-cultural College English Teaching: Current Situation and Theoretical Consideration [J]. Campus English, 2014 (23): 49-49.

[4] Bhang Xiaoping. Research status and theoretical thinking on the construction of intercultural teaching model in College English [J]. Contemporary Educational Practice and Teaching Research (Electronic Edition), 2016 (12X).

[5] Chen Gauguin. Problems and Countermeasures in cross-cultural teaching of College English [D]. Shanghai Foreign Studies University, 2014. 